\title{
The Protective Role of CD59 and Pathogenic Role of Complement in Hepatic Ischemia and Reperfusion Injury
}

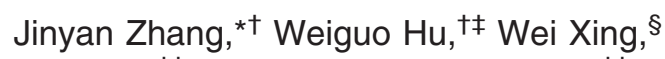 \\ Tao You, ${ }^{\dagger \neq}$ Junming Xu, ${ }^{*}$ Xuebin Qin, ${ }^{\dagger \ddagger}$ and \\ Zhihai Peng* \\ From the Department of General Surgery,* Shanghai First \\ People's Hospital, Shanghai Jiaotong University, Shanghai, \\ China; the Laboratory for Translational Research, ${ }^{\dagger}$ Harvard \\ Medical School, Cambridge, Massachusetts; and the Department \\ of Medicine, ${ }^{\neq}$and the Division of Rheumatology, Immunology \\ and Allergy, ${ }^{\circledR}$ Harvard Medical School, Brigham and Women's \\ Hospital, Boston, Massachusetts
}

Hepatic ischemia-reperfusion injury (IRI) is a major factor influencing graft outcome in liver transplantation, but its mechanism is not well defined. Although complement, including the membrane attack complex (MAC), a terminal product of complement activation, is thought to be involved in the multiple reactions subsequent to the ischemia-reperfusion (IR) process, the role of MAC in the pathogenesis of hepatic IRI requires further investigation. We used a warm ischemia-reperfusion injury model in mice and a syngeneic orthotopic liver transplantation model in rats to define the role of complement, including MAC, in hepatic IR. CD59-deficient mice had more severe liver dysfunction, evidenced by increased aspartate aminotransferase levels and increased injury of liver parenchymal and nonparenchymal cells than did CD59-sufficient mice during warm hepatic IR. Furthermore, complement depletion in CD59-deficient mice by pretreatment with cobra venom factor (CVF) or the genetic introduction of $\mathrm{C} 3$ deficiency partially protected against development of the severe liver dysfunction that occurred in CD59-deficient mice. Severity of liver dysfunction correlated with MAC deposition, apoptotic cells, and increased inflammatory mediators such as tumor necrosis factor $\alpha$. Moreover, depletion of complement with CVF in orthotopic liver transplantation recipient rats attenuated IRI of the donor livers. Taken together, these results highlight the protective role of $\mathrm{CD} 59$ and pathogenic role of complement, including MAC, in the pathogenesis of hepatic IRI. (Am J Pathol 2011, 179:2876-2884; DOI: 10.1016/j.ajpath.2011.08.040)

Liver transplantation is a routine and powerful approach for treatment of patients with acute or chronic liver failure of various causes. ${ }^{1}$ Nevertheless, hepatic ischemia-reperfusion (IR) remains a major deleterious factor influencing graft outcome in organ transplantation. The incidence of primary graft failure (5\% to $15 \%)$ and initial poor function (10\% to $25 \%$ ) is strongly dependent on the extent of ischemia-reperfusion injury $(\mid \mathrm{RI}) .^{2-4} \mid \mathrm{RI}$ also initiates later graft failure by triggering irreversible intrahepatic biliary tract injury (ischemic-type biliary lesion) or by promoting rejection through activation of innate immunity. ${ }^{5}$ At present, because of the shortage of organs for transplantation, the donor pool has been expanded by utilization of marginal organs from old donors or non-heart-beating donors, as well as grafts with prolonged cold storage, and even allografts donated after cardiac death. It is conceivable that grafts from such donors could cause severe liver injury, because they have usually experienced a long ischemia time. To improve the outcome of liver transplantation, therefore, it is imperative to better understand the mechanisms involved in IRI and to design novel therapeutic strategies for prevention of $\mid \mathrm{RI}$.

Ischemia-reperfusion injury is characterized by the presence of activated polymorphonuclear leukocytes, oxygen radical formation, ${ }^{6}$ and cytokine release. ${ }^{7,8}$ The process that temporarily blocks blood supply followed by blood reperfusion to the living donor after the transplantation causes attraction, activation, adhesion, and migration of neutrophils at the site of donor organ, thereby

This work was supported by National Natural Science Foundation of China 30972952.

Accepted for publication August 29, 2011.

Supplemental material for this article can be found at http://ajp. amjpathol.org or at doi: 10.1016/j.ajpath.2011.08.040.

Address reprint requests to Zhihai Peng, M.D., Liver transplant and General Surgery Department, Shanghai First People's Hospital, Shanghai Jiaotong University, Haining Road 100, Building 2, 13th Floor, Hongkou, Shanghai 200080, China. E-mail: zhihai.peng@hotmail.com. 
leading to both local tissue and remote organ damage. ${ }^{9}$ Recently, clinical and experimental studies in several organ systems have shown that IR also results in excessive activation of the complement system, which is indicative of the critical role of complement in the IRI. ${ }^{10-12}$

The complement system, an important mediator of innate immune defense and inflammation, is activated through three different cascades: the classical, alternative, and lectin pathways. ${ }^{13,14}$ All three activation pathways converge at the $\mathrm{C} 3$ level, forming the membrane attack complex (MAC). The MAC forms a macromolecular pore capable of inserting itself into cell membranes and lysing heterologous cells, including bacteria and viruses. ${ }^{15}$ MAC formation in autologous cell membrane plays multiple and complex functions. ${ }^{16}$ Sublytic MAC in endothelial and smooth muscle cells is also an important mediator of cellular signals that trigger mitogenic effects ${ }^{17}$ and release growth factors such as basic fibroblast growth factor (bFGF) and platelet-derived growth factor (PDGF), as well as cytokines such as IL-1 and monocyte chemotactic protein-1 (MCP-1). ${ }^{18,19}$ To protect autologous cells from MAC-mediated attack, an array of complement regulators have evolved to restrict complement activation, including CD59. A glycosyl-phosphatidylinositol (GPI)-linked membrane protein, CD59 strongly restricts MAC formation by preventing $\mathrm{C} 9$ incorporation and polymerization. ${ }^{20-22}$

Experimental and clinical evidence indicates that IR triggers complement activation in several organs. ${ }^{23} \mathrm{Re}-$ cently, using a novel inhibitor CR2-Crry to inhibit MAC formation and $\mathrm{C} 3$ activation at the site of complement activation, He et $\mathrm{al}^{24}$ demonstrated that an enhanced susceptibility to IRI of steatotic livers was associated with complement activation in a mouse model. Additionally, C6 deficiency in rats protects against ischemia damage in rat orthotopic liver transplantation (OLT) recipients, which indicates the role of MAC in the pathogenesis of hepatic IRI. ${ }^{25,26}$ Nonetheless, the protective role of CD59 and the pathogenic role of complement, including MAC, in the pathogenesis of IRI still require further investigation.

To assess the role of CD59 and MAC in warm IRI, we used $m C d 59 a$ and $m C d 59 b$ double-knockout mouse model $^{27}$ and our own mCd59a, mCd59b, and C3 tripleknockout mouse model, together with a complement depletion method [ie, preadministration of $\mathrm{mCd} 59 \mathrm{ab} \mathrm{b}^{-1-}$ mice with cobra venom factor (CVF)]. Furthermore, to extend the present study to a clinically relevant context of liver transplantation, rats with complement deficiency induced by CVF were used to investigate the role of complement activation in IRI after syngeneic OLT.

\section{Materials and Methods}

\section{Animals}

All animals were housed in a specific pathogen-free facility and were confirmed to be negative for common murine viral pathogens by routine sera analysis. All mice on a C57BL/6 (B6) genetic background were 8 to
12 weeks old, with 20 to $30 \mathrm{~g}$ body weight. $m C d 59 a$ and $m C d 59 b$ double-knockout mice $\left(\mathrm{mCd}^{2} 9 \mathrm{ab}^{-1-}\right)$ and $m C d 59 a, m C d 59 b$, and $m C 3$ triple-knockout mice $\left(\mathrm{mCd} 59 \mathrm{ab} \mathrm{b}^{-1-} / \mathrm{mC}^{-/-}\right)$in a B6 background were generated at the Laboratory for Translational Research at Harvard Medical School as previously described by Qin et al. ${ }^{27}$ In the rat experiment, all adult male Wistar rats (200 to $250 \mathrm{~g}$ body weight) were purchased from the Animal Facility of Shanghai Jiao Tong University. The mouse experiments were conducted at the Laboratory for Translational Research at Harvard Medical School and the rat experiments at the Department of General Surgery of Shanghai First People's Hospital at Shanghai Jiao Tong University. The protocols for hepatic IRI were approved by the respective animal committees of Harvard Medical School and Shanghai Jiao Tong University.

\section{Cells}

The hepatoma cell line Hep3B was obtained from the Shanghai cell bank of the Chinese Academy of Sciences. Cells were propagated in Dulbecco's modified Eagle's medium supplemented with $10 \%$ heat-inactivated fetal calf serum, $2 \mathrm{mmol} / \mathrm{L}$ L-glutamine, and $1 \%$ penicillin/ streptomycin (Gibco; Invitrogen, Carlsbad, CA).

\section{Hepatic Warm IRI and Complement Depletion in Mice}

Mice were anesthetized by mixed isoflurane (Baxter International, Deerfield, IL) inhalation (5\%) with oxygen at 3 $\mathrm{L} / \mathrm{min}$, and were subjected to total warm hepatic ischemia as described previously. ${ }^{28}$ After 45 minutes of hepatic ischemia, surviving mice were sacrificed at 6,12 , or 24 hours after reperfusion.

Pretreatment with CVF (Quidel, San Diego, CA) is a well established method to deplete complement for assessing the role of complement in animal models of human diseases. ${ }^{29}$ Thus, CVF was used for induction of complement depletion in vivo for $\mathrm{mCd} 59 \mathrm{ab} b^{+/+}$and $m C D 59 a b^{-1-}$ mice with injection of a single dose (1.5 $\mu \mathrm{g} / \mathrm{g}$ i.p.) at 24 hours before hepatic IR.

\section{Surgical Procedure of Hepatic IR by Syngeneic OLT in Rat}

To deplete complement in the rats, CVF was administered ( $1 \mathrm{~g} / \mathrm{kg}$ body weight, i.p.) to recipient rats 24 hours before syngeneic OLT. Donor rats underwent isoflurane inhalation anesthesia. After a flushing via the cannulated portal vein with $20 \mathrm{~mL}$ of heparinized University of Wisconsin solution (DuPont Pharmaceuticals, Wilmington, $\mathrm{DE}$ ), the liver was isolated and stored at $4^{\circ} \mathrm{C}$ for 2 hours before transplantation. A cuff was used for revascularization for the portal vein and inferior vena cava after the superior vena cava was reconstructed with $6-0$ running suture (Prolene; Ethicon, Somerville, NJ) in rat nonarterialized OLT. ${ }^{30}$ The abdomen was closed in a double layer using 5-0 USP suture (Monocryl; Ethicon), and $1 \mathrm{~mL}$ sterile lactated Ringer's solution (Baxter International) 
was administered subcutaneously to compensate for operative fluid loss.

\section{Assessment of Biochemistry and Chemokine}

Blood aspartate aminotransferase (AST) and alanine aminotransferase (ALT) levels were determined spectraphotometrically using plasma prepared from collected blood, as described previously. ${ }^{31}$ AST and ALT values were expressed in international units per liter (IU/L). Plasma TNF- $\alpha$, IL-6, IL-12, and MIP-2 levels were determined with a Bio-Plex multiplex cytokine assay (Bio-Rad Laboratories, Hercules, CA), using a protocol described previously. ${ }^{32}$ sP-selectin and plasma Von Willebrand factor (VWF) activity were measured using an ELISA kit (R\&D Systems, Minneapolis, MN), as described previously. ${ }^{33,34}$ To monitor the kinetics of complement depletion, serum C3 levels of mice with and without CVF treatment were measured by ELISA using $F\left(a b^{\prime}\right) 2$ fragments of goat anti-mouse $C 3$ as capture antibody and peroxidase-conjugated goat antimouse $\mathrm{C} 3$ as the second antibody. ${ }^{35}$ Optical density $\left(\mathrm{OD}_{414}\right)$ was determined in a 96-well plate by means of an ELISA plate reader. All samples were tested in duplicate.

\section{Evaluation of Liver Histology and Injury}

Liver tissue were fixed in 10\% formalin and processed for paraffin embedding. Sections of $4-\mu m$ thickness were cut for H\&E staining. A pathologist (W.X.), in a blinded fashion, evaluated and graded the severity of liver damage in the sections based on sinusoidal congestion, cytoplasmic vacuolization, hepatocellular necrosis, and neutrophil infiltration, as described previously. ${ }^{36}$

In brief, a grade of 0 indicates minimal or absent necrosis; grade 1 indicates individual mild injury with cytoplasm vacuolization and focal nuclear pyknosis; grade 2 indicates moderate to severe injury with extensive nuclear pyknosis, cytoplasmic hypereosinophilia, and loss of intercellular borders; and grade 3 indicates severe necrosis with disintegration of hepatic cords, hemorrhage, and neutrophil infiltration. Ten high-powered fields per section were analyzed in relation to the central vein to determine the percentage of necrotic cells.

\section{Detection of in Situ Cell Death}

In situ apoptosis was evaluated by TUNEL staining (Roche Applied Science, Indianapolis, IN) and immunohistochemistry staining with anti-active caspase-3 antibodies according to the manufacturer's instructions. Fluorescent staining results were analyzed and evaluated using Image-Pro Plus version 4.5 software (Media Cybernetics, Silver Spring, MD). The percentage of TUNELpositive cells served as the apoptosis index. The apoptosis rate confirmed by immunohistochemistry staining with anti-active caspase-3 antibodies was calculated as the number of activated caspase-3 stained cells per 1000 hepatocytes.

\section{Determination of MAC Deposition in Liver Tissue}

Frozen sections were stained with rabbit anti-rat C9, which cross-reacts with mouse C9 (kindly provided by Dr. B. Paul Morgan, University of Wales), as we have described previously. ${ }^{35,37}$

\section{Cytotoxicity Assay}

Hep3B cells were used because this cell line has been demonstrated to highly express human CD59. ${ }^{38}$ We followed the same protocol as described previously ${ }^{38,39}$ to culture the cells and to perform complement-mediated cytotoxicity assay. Briefly, $10^{5}$ cells were treated with anti-hCD59 antibody (Bric 229 clone) for 40 minutes. After three washings with PBS, the cells were incubated at $37^{\circ} \mathrm{C}$ for 1 hour with a rabbit anti-human asialoglycoprotein receptor (ASGPR) polyclonal antibody (Abcam, Cambridge, UK) for activating the complement classical pathway, and $25 \%$ human serum or heat-inactivated human serum as a source of complement. We used cells cultured in the medium as untreated control. Supernatant (20 $\mu \mathrm{L}$ ) was collected from each well after centrifugation and processed with $150 \mu \mathrm{L}$ europium solution (DELFIA; PerkinElmer-Wallac, Turku, Finland) for fluorescent staining. The fluorescence was measured with a 1420 multilabel counter (PerkinElmer-Wallac).

\section{Statistical Analysis}

Comparisons between two groups were performed using an unpaired $t$-test. Comparisons across multiple groups and various time points were analyzed using analysis of variance followed by a Fisher's protected least significant difference (PLSD) post hoc test. $P \leq 0.05$ was considered statistically significant. All data were analyzed using SigmaStat version 3.5 software (SPSS, Chicago, IL). Values are presented as means \pm SEM.

\section{Results}

\section{Accelerated IRI in CD59-Deficient Mice Is Complement Dependent}

To define the protective role of CD59 and pathogenic role of MAC in the pathogenesis of IRI, we used $\mathrm{mCd} 59 \mathrm{ab} \mathrm{b}^{-/-}$ mice and an established murine IR model. AST levels, a marker for liver function routinely tested in clinical laboratories, were used to monitor the dynamic change of liver function. At 12 hours after warm reperfusion, $m C d 59 a b^{-/-}$mice had significantly higher levels of AST, compared with CD59-sufficient wild-type mice $(P<0.05$; Figure 1A). Also, levels of AST and ALT in $m C d 59 a b^{-/-}$ mice tended to be higher than those of $\mathrm{mCd} \mathrm{Caab^{+/+ }}$ mice, although the difference did not reach statistical significance at 6 hours or 24 hours after reperfusion (Figure $1 \mathrm{~A}$; see also Supplemental Figure S1A at $h t t p: / /$ ajp.amjpathol.org). These results indicate that CD59 protects against hepatic IRI. 

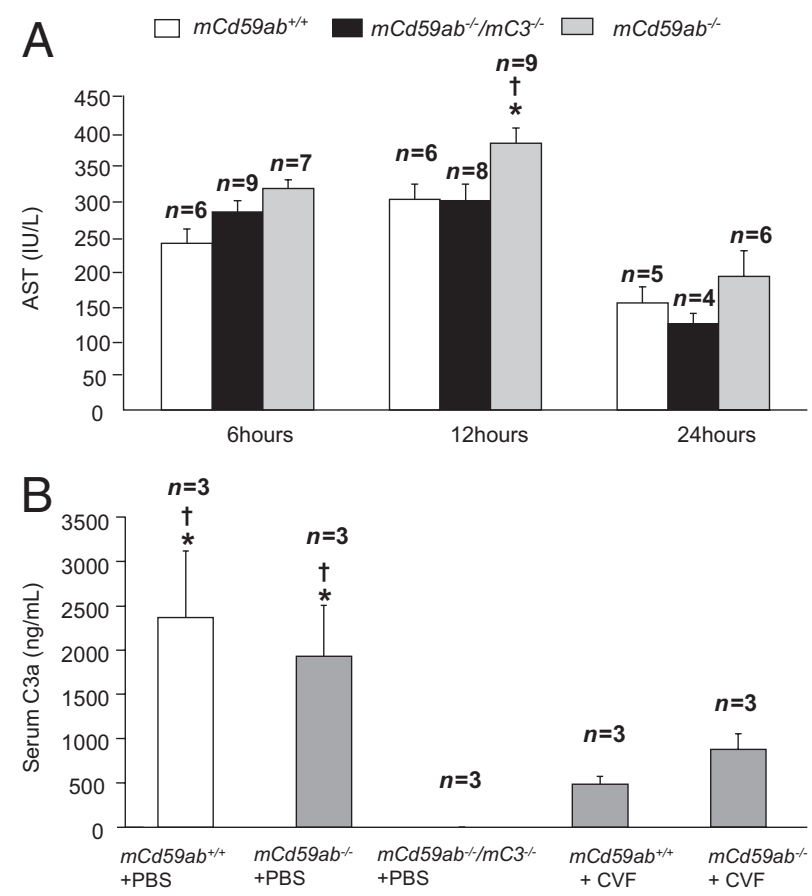

Figure 1. CD59 deficiency accelerated liver IRI. A: Serum levels of AST measured after ischemia and 6, 12, and 24 hours of reperfusion. ${ }^{*} P<0.05$ versus $m C d 59 a b^{+1+} ;{ }^{\dagger} P<0.05$ versus $m C d 59 a b^{-1-} / m C 3^{-1-}$. B: Serum levels of $\mathrm{C} 3 \mathrm{a}$ measured after ischemia and 12 hours of reperfusion. The mice were pretreated with PBS buffer or CVF. ${ }^{*} P<0.05$ versus $m C d 59 a b^{-/-} / \mathrm{mC3}^{-/-} ;{ }^{\dagger} P<0.05$ versus CVF pretreatment. Data are expressed as means \pm SEM

In addition to its anti-MAC role, CD59 has a complement-independent function in regulating activity of $\mathrm{NK}, \mathrm{B}$, and $T$ cells, ${ }^{37,40,41}$ which may also contribute to hepatic $|R|$. To define the underlying mechanism by which the deficiency of CD59 accelerates the IRI, we generated $m \mathrm{~m} d 59 a b^{-1-} / \mathrm{mC3}^{-1-}$ mice by crossing $\mathrm{mC3}$ C3-deficient mice $\left(\mathrm{mC3}^{-/-}\right)$with $\mathrm{mCd} 59 \mathrm{ab}{ }^{-1-}$ mice. Absence of $\mathrm{C} 3$ in $\mathrm{mCd} 59 \mathrm{ab} \mathrm{b}^{-1-} / \mathrm{C} 3^{-1-}$ functionally confirmed the C3 deficiency in $m C d 59 a b^{-1-}$ (Figure 1B). At 12 hours after warm IR, the $m C d 59 a b^{-/-} / \mathrm{C}^{-/-}$had a significantly lower level of AST, compared with $m \mathrm{Cd} 59 \mathrm{ab}{ }^{-1-}$ mice. At 6 and 24 hours after reperfusion, AST levels tended to be

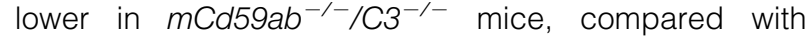
mCd59ab ${ }^{-1-}$ mice (Figure 1A). Furthermore, there were no significant difference at the level of AST between $m C d 59 a b^{-1-} / \mathrm{C}^{-1-}$ and $m C d 59 a b^{+/+}$mice (Figure $1 \mathrm{~A}$ ). These data indicate that the accelerated $|R|$ in CD59deficient mice is complement-dependent and that the MAC contributes to the development of IRI.

\section{Increased MAC Deposition in mCd59ab ${ }^{-1-}$ Mice Correlates with Increased Apoptotic Cell Numbers and Liver Damage after Hepatic IRI}

Because CD59 is a key regulator for the formation of MAC, ${ }^{12}$ we analyzed MAC deposition through immunofluorescence assay for $\mathrm{C9}$. Consistently, we observed significantly increased MAC deposition in $\mathrm{mCd} 59 \mathrm{ab} \mathrm{b}^{-1-}$ than in $m \mathrm{Cd} 59 \mathrm{ab} b^{+/+}$or $\mathrm{mCd} 59 \mathrm{ab} b^{-/-} / \mathrm{C} 3^{-/-}$mice (Figure 2B). His- tological analysis of liver tissues revealed much more evident inflammation of $m C d 59 a b^{-1-}$ livers, with remarkable hepatocyte swelling and vacuolization, sinusoidal congestion, spotty necrosis in centrilobular areas, and diffuse neutrophil infiltration in the portal spaces, compared with $m \mathrm{Cd} 59 \mathrm{ab} \mathrm{b}^{+/+}$or $\mathrm{mCd} 59 \mathrm{ab} \mathrm{b}^{-/-} / \mathrm{C} 3^{-/-}$mice (Figure 2, $\mathrm{A}$ and $\mathrm{C}$ ). These results highlight the critical roles of MAC in the pathogenesis of hepatic IRI.

\section{Increased TNF- $\alpha, v W F$, and P-Selectin Levels in mCd59ab ${ }^{-1-}$ Mice after Warm IRI}

The inflammatory response to hepatic IR is associated with an increase in cytokine production. ${ }^{42}$ The biphasic pattern of hepatic IRI was characterized by Kupffer cell activation and release of proinflammatory cytokines in the early phase, followed by massive neutrophil infiltration and further production of the inflammatory mediators in the late phase. To investigate the molecular mechanisms by which MAC may be involved in $\mid R I$, we measured plasma levels of TNF- $\alpha$, IL-12, IL-6, and MCP-1, the cytokines commonly elevated in liver damage, ${ }^{43,44}$ at 6 and 12 hours after reperfusion. At the 12-hour time point, plasma TNF- $\alpha$ levels of $m C d 59 a b^{-1-}$ mice were significantly higher than those of $m \mathrm{Cd} 59 \mathrm{ab} b^{+/+}$and $\mathrm{mCd} 59 \mathrm{ab} b^{-/-} / \mathrm{C3}^{-/-}$(Figure 3). Fur-

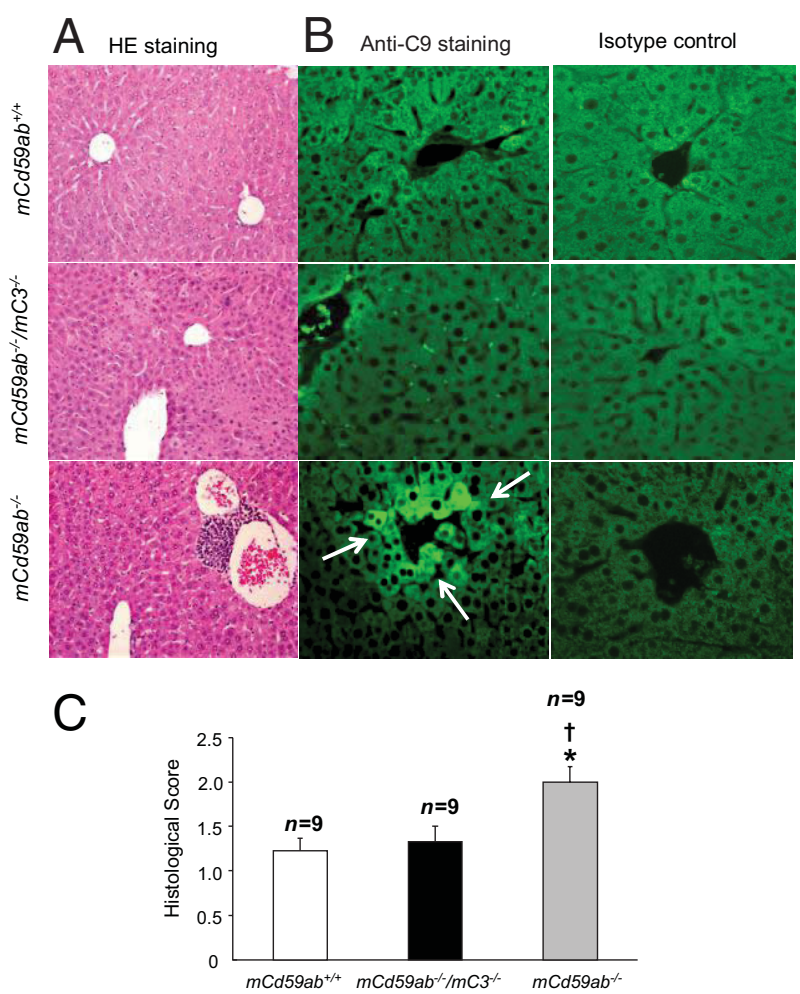

Figure 2. CD59 deficiency Increased MAC deposition in liver after IR. A: Representative micrographs show liver histopathology, H\&E staining, after 12 hours of liver ischemia. Original magnification, $\times 20$. B: Representative micrographs show C9 deposition in liver (arrows), stained by rabbit anti-rat C9 or isotype control plus fluorescein isothiocyanate-conjugated secondary antibodies after 12 hours of liver ischemia. Original magnification, $\times 40$. C: Histological injury score of liver tissues after IR. The mean score for each rat was calculated out of 10 evaluations. Data are expressed as medians with $25 \%$ to $75 \%$ interquartile range. Mann-Whitney rank sum test. ${ }^{*} P<0.05$ versus $m C d 59 a b^{-1-} / \mathrm{mCz}^{-1-} ;{ }^{\dagger} P<0.05$ versus $m C d 59 a b^{+/+}$. 


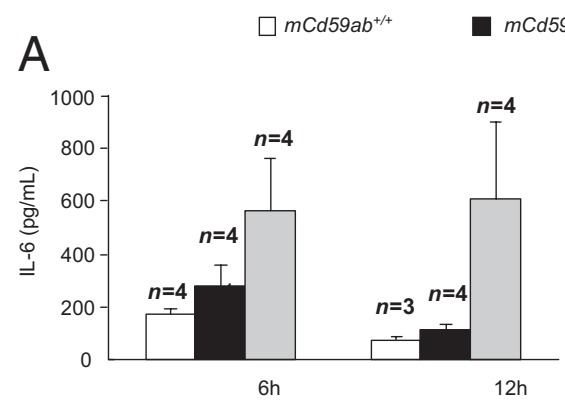

C

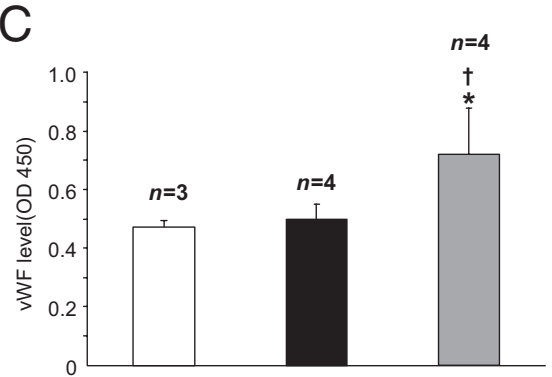

$a b^{-/ / m C 3^{--}} \square m C d 59 a b^{-1-}$

B

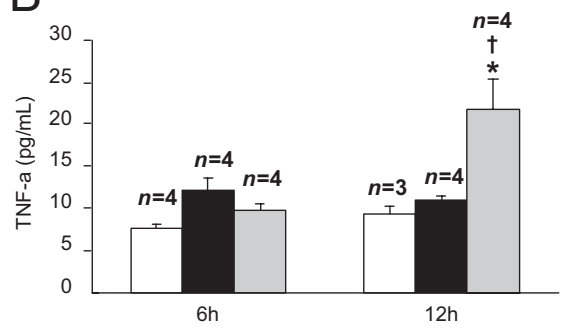

D

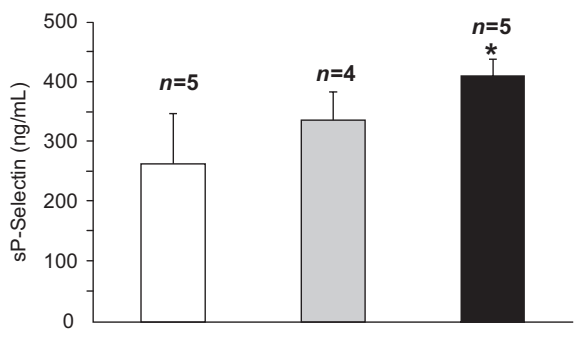

Figure 3. Increased levels of cytokines, vWF and P-selectin in $\mathrm{mCd} 59 \mathrm{ab} \mathrm{b}^{-1-}$ mice after warm IRI. Levels of cytokines IL-6 (A) and TNF- $\alpha$ (B) in different IR mice at 6 and 12 hours. ${ }^{*} P<0.05$ versus $m C d 59 a b^{-/-} / \mathrm{mCz}^{-/-}$at 12 hours; ${ }^{\dagger} \mathrm{P}<$ 0.01 versus $m C d 59 a b^{+/+}$at 12 hours. C: vWF levels were measured after ischemia and 2 hours of reperfusion. ${ }^{*} P<0.05$ versus $m C d 59 a b^{-/-}$, $m C 3^{-/-} ;{ }^{\dagger} P<0.05$ versus $m C d 59 a b^{+/+}$. D: Serum levels of P-selectin in different IR mice were measured after ischemia and 2 hours of reperfusion. ${ }^{*} P<0.05$ versus $m C d 59 a b^{+/+}$. Data are expressed as means \pm SEM. thermore, the plasma IL-6 levels of $m \mathrm{Cd} 59 a b^{-1-}$ mice tended to be higher than those of $m C d 59 a b^{+/+}$and $m \mathrm{Cd} 59 \mathrm{ab} \mathrm{b}^{-1-} / \mathrm{C} 3^{-1-}$ (Figure 3, A and B). There were no significant differences for levels of $\mathrm{IL}-12$ and MCP-1 among the groups (data not shown). These results indicate that increased TNF- $\alpha$ and IL- 6 may be associated with the development of MAC-accelerated hepatic IRI.

We also measured plasma levels of VWF and SP-selection, the biomarkers for endothelial dysfunction and platelet activation, ${ }^{34,45,46}$ to define the cellular mechanisms of complement in the IRI. $m C d 59 a b^{-1-}$ mice had significantly higher level of plasma vWF and sP-selectin than did $\mathrm{mCd} 59 \mathrm{ab} \mathrm{b}^{+/+}$and $\mathrm{mCd} 59 \mathrm{ab} \mathrm{b}^{-/-} / \mathrm{mC}^{-1-}$ mice at 2 hours after liver reperfusion, but not at 6 or 12 hours (Figure 3, C and D). These data indicate that MAC-mediated endothelial damage and platelet activation during the early stage of IR may also be involved in the development of hepatic IRI.

\section{Complement Depletion in mCd59-Deficient and mCd59-Sufficient Mice Protects against Development of IR}

To further evaluate complement activation in the pathogenesis of IR, we depleted complement activity in $m C d 59 a b^{-1-}$ and $m C d 59 a b^{+/+}$mice by pretreatment with CVF, a strong complement activator that causes complement consumption after injection. ${ }^{47}$ Complement depletion was confirmed by a significantly lower level of $\mathrm{C} 3 \mathrm{a}$ in the mice after CVF pretreatment, compared with vehicle treatment (Figure 1B). We selected the time point of 12 hours after reperfusion to assess the role of complement activation in the pathogenesis of IR because we detected the maximal difference in liver function among the three groups at this time point (Figure 1A). CVFpretreated $\mathrm{mCd} 59 \mathrm{ab} \mathrm{b}^{-/-}$had significantly lower levels of AST, compared with vehicle-pretreated mice (Figure 4). This result further confirms the finding that the acceler- ated IRI in CD59-deficient mice is complement-dependent. Moreover, CVF-pretreated $m C d 59 a b^{+/+}$mice had significantly lower levels of AST than did vehicle-pretreated mice. There was no significant difference in AST levels between CVF-pretreated $m \mathrm{Cd} 59 a b^{+/+}$and $m C d 59 a b^{-1-}$ mice (Figure 4). Taken together, these results suggest that complement activation also plays a critical role in the pathogenesis of IR in both CD59-sufficient and CD59-deficient conditions.

\section{CVF-Mediated Complement Depletion Attenuates IRI after Liver Transplantation in Rat}

To investigate the role of complement in both warm and cold ischemia followed by sequential reperfusion during liver transplantation, a clinically relevant condition, we depleted the complement activity by pretreatment of CVF in Wistar recipient rats at 24 hours before OLT. Syngeneic OLT between Wistar rats was chosen to exclude the inevitable interference of complement activation in allogeneic OLT. We found that CVF-pretreated recipient rats had significantly lower levels of AST (Figure 5A) and ALT

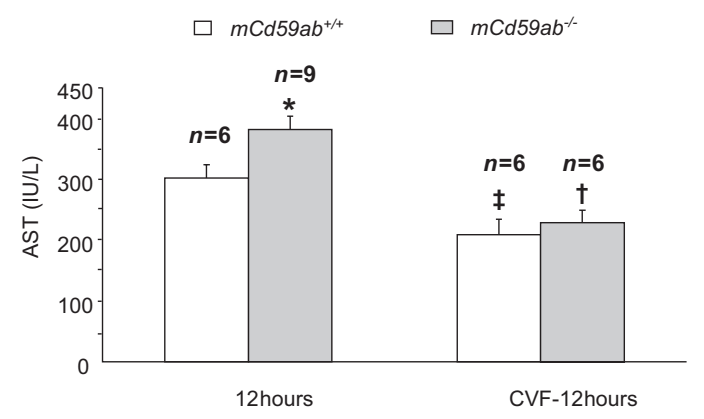

Figure 4. Complement deficiency partially rescues liver IRI. Serum levels of AST were measured after ischemia and 12 hours of reperfusion. ${ }^{*} P<$ 0.05 versus $m C d 59 a b^{+/+} ;{ }^{\dagger} P<0.05$ versus $m C d 59 a b^{-/-} ;{ }^{\ddagger} P<0.01$ versus $m C d 59 a b^{+/+}$. Data are expressed as means \pm SEM. 

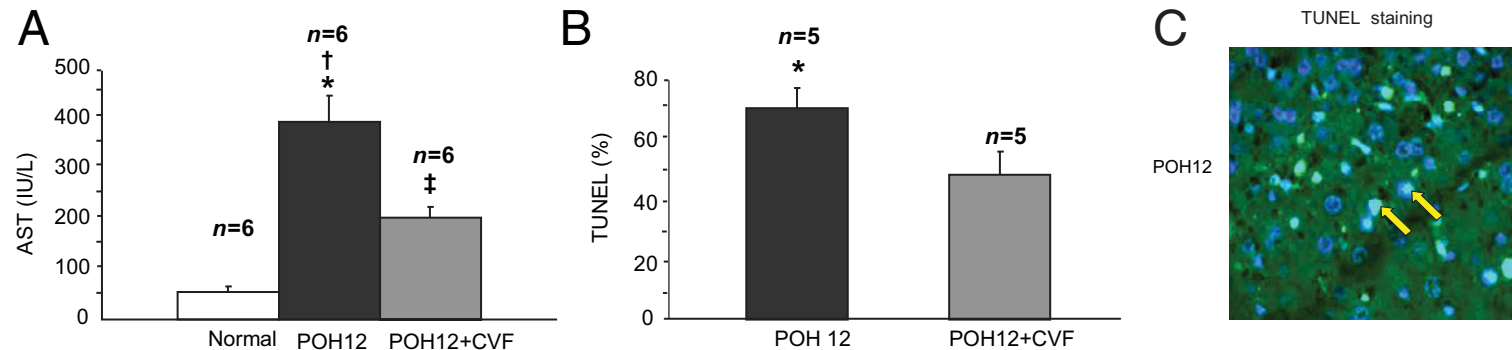

Figure 5. IRI in rats with or without CVF pretreatment at 12 hours after syngeneic OLT (POH12). A: AST level in treated and untreated rats. ${ }^{*} P<0.05$ versus POH $12+\mathrm{CVF} ;{ }^{\dagger} P<0.01$ versus normal; ${ }^{\ddagger} P<0.05$ versus normal. B: Apoptotic hepatocytes by TUNEL assay in treated or untreated rats. ${ }^{*} P<0.05$ versus POH12+CVF. C: Apoptotic hepatocytes by TUNEL assay in rats without CVF at 12 hours after syngeneic OLT. Note intense apoptosis in the liver of rats after 12 hours of OLT. Fluorescent signal highlights the nuclei (arrows).

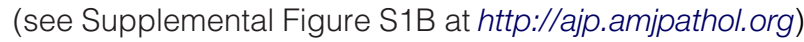
associated with apoptotic cells detected by TUNEL (Figure 5, B and C) and caspase 3 immunohistochemistry staining (see Supplemental Figure S2 at http://ajp. amjpathol.org), and had decreased hepatocellular necrosis, sinusoidal congestion, and neutrophil infiltration (Figure 6), compared with nontreated rats. Moreover, CVFpretreated rats had reduced MAC deposition, relative to nontreated rats (data not shown). These results further support the critical roles of complement activation in the pathogenesis of hepatic IRI after OLT.

\section{Discussion}

Here, we report the protective role of CD59 in hepatic IRI determined in mCd59a and mCd59b double-knockout mice. Although the protective role of CD59 in hepatic IRI has not been defined previously, the protective role of CD59 in renal IRI $\left.\right|^{26}$ and in cerebral ischemia ${ }^{48}$ has been elucidated by utilization of deficiency of the mCd59a, a primary murine. ${ }^{27,49,50}$ These results, together with the fact that CD59 is universally expressed in almost of all cells in a variety of organs, indicate that CD59 may protect against the IRI in organs other than liver, kidney, and brain. Furthermore, CR2-CD59, a novel targeting complement inhibitors for complement activation sites, recently developed by Tomlinson's research group ${ }^{51}$ may provide a new avenue to protect organs and donor grafts, including liver, from IRI.

We also demonstrated that $\mathrm{C} 3$ deficiency rescues accelerated hepatic IRI in $m C d 59$ deficient mice, and that MAC deposition correlates with the severity of hepatic IRI. These results shed light on the critical role of MAC in the pathogenesis of hepatic IRI. Consistent with these findings, the critical role of complement (including MAC) in liver transplantation has been demonstrated in an OLT C6-deficient rat model, ${ }^{25}$ and similarly for gastrointestinal and renal IRI in an anti-murine C5 antibody study ${ }^{52}$ and in mice deficient in $\mathrm{C} 3, \mathrm{C} 4, \mathrm{C} 5$, and $\mathrm{C} 6,{ }^{53}$ respectively. Nonetheless, the molecular and cellular mechanisms by which MAC accelerates organ IRI remain elusive. In the present study, we have demonstrated that inhibition of CD59 function in vitro sensitizes hepatocyte cells to complement-mediated cytotoxicity (see Supplemental Figure S3 at http://ajp.amjpathol.org), a finding in accord with results reported by Halme et al. ${ }^{38}$ MAC also mediates apoptotic effect on cells. ${ }^{38,39,54}$ Consistently, we have demonstrated that pretreatment to deplete complement protects hepatocytes against complement-mediated apoptotic effect. Moreover, we found that the potential effect of MAC on endothelial damage and platelet acti-

A $10 x$
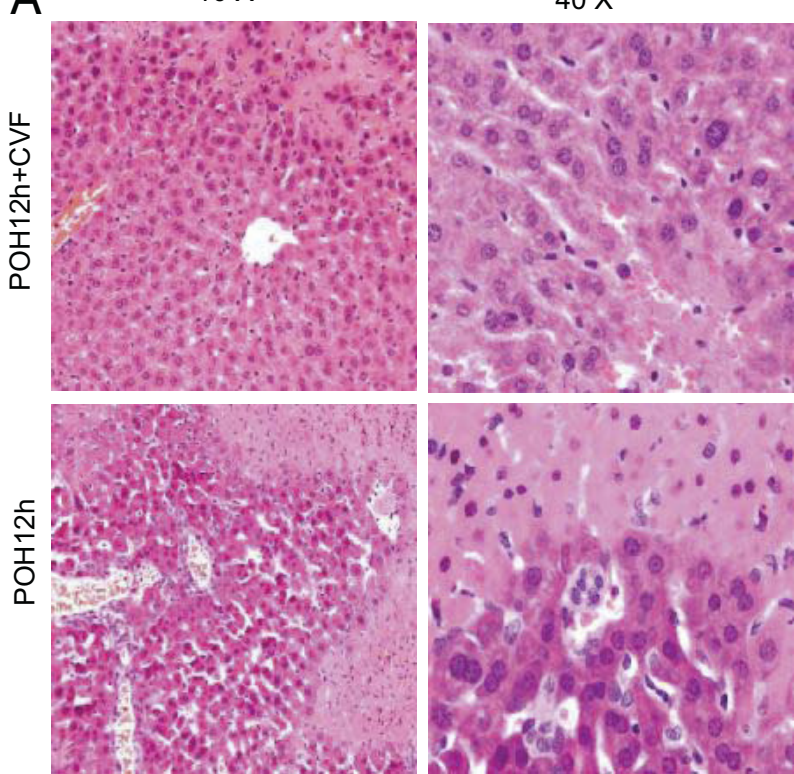

B

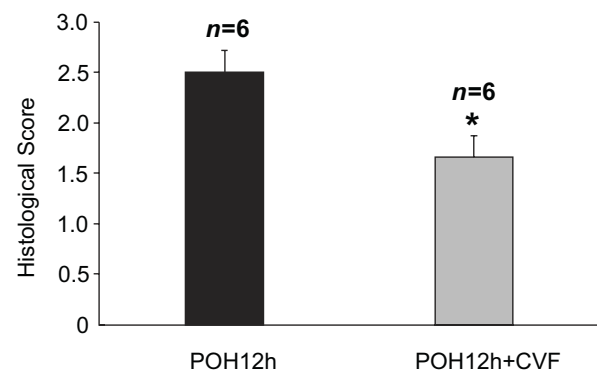

Figure 6. Complement depletion with CVF attenuates IR injury after liver transplantation in rat. Representative images from different animals are shown. A: Liver histopathology in H\&E-stained liver sections was examined at original magnification of $\times 10$ and $\times 40$. In CVF-treated liver $(\mathrm{POH} 12 \mathrm{~h}+\mathrm{CVF})$, the area of necrosis is associated with intense neutrophil recruitment. In CVF-untreated liver (POH12h), severe hemorrhagic necrosis with widespread destruction of hepatic architecture is observed, but with less neutrophil accumulation. B: Histological injury score of liver tissue in rats treated or untreated CVF after syngeneic OLT 12 hours: The mean score for each rat was calculated out of 10 evaluations. Data are expressed as medians with $25 \%$ to $75 \%$ interquartile range. Mann-Whitney rank sum test. ${ }^{*} P<0.05$. 
vation may contribute to the development of IRI. It is well documented that sinusoidal endothelial cells are susceptible to ischemia injury during liver transplantation. ${ }^{55} \mathrm{Ex}$ tensive clinical and experimental studies have shown an increase in VWF in the peripheral blood of patients who received OLT and in rats that received heart or lung grafts. ${ }^{56-60}$ Plasma levels of VWF increased early after partial hepatectomy, probably because of both acutephase reaction and decreased degradation. ${ }^{60}$ P-selectin levels correlate with graft viability in cold-preserved rat livers. ${ }^{57}$

Consistently, we observed significantly increased vWF and P-selectin levels at 2 hours after liver reperfusion in $m C d 59 a b^{-1-}$ mice, compared with $\mathrm{mCd}^{-19 a b^{+/+}}$or $\mathrm{mCd} 59 \mathrm{ab} \mathrm{b}^{-1-} / \mathrm{mC}^{-1-}$ mice. Our results also indicate that TNF- $\alpha$ and IL-6 may participate in the pathogenesis of MAC-accelerated IRI. It has been reported that IL-6 prevents fatty liver transplantation failure by improving microcirculation, ${ }^{61}$ and that it protects against mitochondrial DNA damage in the liver. ${ }^{62}$ TNF- $\alpha$, however, plays paradoxical dual roles in both prevention and promotion of $|R|$ in the liver tissue. Recent reports indicate that inhibiting TNF- $\alpha$ production improves donor livers. ${ }^{63,64}$ Although our results highlight the critical role of MAC in the pathogenesis of hepatic IRI, the MAC-mediated endothelial damage and platelet activation, as well as inflammatory effects in the pathogenesis, still require further investigation.

In addition, we have demonstrated that complement activation plays a critical role not only in CD59-deficient mice but also in CD59-sufficient mice, and that the liver damage resulted from hepatic IRI in CVF-pretreated CD59-deficient mice is the same as that in CVF-pretreated CD59-sufficient mice. The difference in hepatic IRI between CD59-deficient and CD59-sufficient mice indicates the critical role of MAC in the pathogenesis. These results indicate that bioproducts of complement activation such as C3a and C5a may participate in the pathogenesis of hepatic IRI, which requires further investigation with $\mathrm{C} 3 \mathrm{a}$ and $\mathrm{C} 5 \mathrm{a}$ receptor-deficient mice. Consistently, we demonstrated that complement depletion in the recipient rats significantly protects the donor liver against hepatic IRI. This result further suggests that complement such as $\mathrm{C} 3 \mathrm{a}, \mathrm{C} 5 \mathrm{a}$, and MAC may play a critical role in hepatic IRI in liver transplantation. These results are consistent with findings reported by $\mathrm{He}$ et al..$^{24} \mathrm{It}$ is well established that $\mathrm{C} 3 \mathrm{a}$ and $\mathrm{C} 5 \mathrm{a}$ bind with high affinity to the $\mathrm{C} 5 \mathrm{a}$ receptor $(\mathrm{C} 5 \mathrm{aR})$ on polymorphonuclear leukocytes, monocytes, and macrophages ${ }^{29}$ to stimulate oxidative metabolism and the production of reactive oxygen species in neutrophils and T cells, thereby leading to the amplification of inflammatory responses. ${ }^{65,66}$

It is worth noting that we did not have any primary reasons to select AST instead of ALT as a main parameter for the detection of the degree of liver injury in our experiments. It has been widely accepted that both AST and ALT are standard clinical and experimental biomarkers for monitoring the liver damage. ${ }^{31}$ Consistently, we demonstrated that either AST or ALT levels in the OLT rats are significantly higher than those in OLT recipient rats pretreated with CVF. Given the limited amount of serum obtained from the mice, we measured the levels of serum ALT only in a few mice at 6 hours after IR. We also observed no significant difference in serum ALT levels among the three groups (see Supplemental Figure S1A at http://ajp.amjpathol.org), which is similar to the findings for serum AST among the three groups at 6 hours after IR.

Taken together, our present results and results reported previously highlight the roles of $\mathrm{C} 3 \mathrm{a}, \mathrm{C} 5 \mathrm{a}$, and MAC in the pathogenesis of the organ IRI. Understanding of their relative roles and the underlying mechanisms in the pathogenesis of complement-mediated donor $\mid \mathrm{RI}$ is important for the design of therapeutic strategies for the prevention of donor IRI, and requires further investigation.

\section{References}

1. Parker BM, Cywinski JB, Alster JM, Irefin SA, Popovich M, Beven M, Fung $\mathrm{JJ}$ : Predicting immunosuppressant dosing in the early postoperative period with noninvasive indocyanine green elimination following orthotopic liver transplantation. Liver Transpl 2008, 14:46-52

2. Ploeg RJ, D'Alessandro AM, Hoffmann RM, Eckhoff D, Isaacs R, Knechtle SJ, Pirsch JD, Stegall MD, Kalayoglu M, Belzer FO: Impact of donor factors and preservation on function and survival after liver transplantation. Transplant Proc 1993, 25:3031-3033

3. Katz E, Mor E, Patel T, Theise N, Emre S, Schwartz ME, Miller CM Association between preservation injury and early rejection in clinical liver transplantation: fact or myth? Transplant Proc 1993, 25:19071908

4. Lemasters JJ, Thurman RG: Reperfusion injury after liver preservation for transplantation. Annu Rev Pharmacol Toxicol 1997, 37:327-338

5. Buis $\mathrm{Cl}$, Hoekstra $\mathrm{H}$, Verdonk RC, Porte RJ: Causes and consequences of ischemic-type biliary lesions after liver transplantation. J Hepatobiliary Pancreat Surg 2006, 13:517-524

6. Zweier JL, Talukder MA: The role of oxidants and free radicals in reperfusion injury. Cardiovasc Res 2006, 70:181-190

7. Motoki A, Adachi N, Liu K, Takahashi HK, Nishibori M, Yorozuya T, Arai T, Nagaro T: Suppression of ischaemia-induced cytokine release by dimaprit and amelioration of liver injury in rats. Basic Clin Pharmacol Toxicol 2008, 102:394-398

8. Mbachu EM, Klein LV, Rubin BB, Lindsay TF: A monoclonal antibody against cytokine-induced neutrophil chemoattractant attenuates injury in the small intestine in a model of ruptured abdominal aortic aneurysm. J Vasc Surg 2004, 39:1104-1111

9. Watts JA, Kline JA: Bench to bedside: the role of mitochondrial medicine in the pathogenesis and treatment of cellular injury. Acad Emerg Med 2003, 10:985-997

10. Karpel-Massler G, Fleming SD, Kirschfink M, Tsokos GC: Human C1 esterase inhibitor attenuates murine mesenteric ischemia/reperfusion induced local organ injury. J Surg Res 2003, 115:247-256

11. Atkinson C, Song H, Lu B, Qiao F, Burns TA, Holers VM, Tsokos GC, Tomlinson S: Targeted complement inhibition by $\mathrm{C} 3 \mathrm{~d}$ recognition ameliorates tissue injury without apparent increase in susceptibility to infection. J Clin Invest 2005, 115:2444-2453

12. Jha P, Sohn JH, Xu Q, Nishihori H, Wang Y, Nishihori S, Manickam B, Kaplan HJ, Bora PS, Bora NS: The complement system plays a critical role in the development of experimental autoimmune anterior uveitis. Invest Ophthalmol Vis Sci 2006, 47:1030-1038

13. Tomlinson S: Complement defense mechanisms. Curr Opin Immunol 1993, 5:83-89

14. Qin X, Gao B: The complement system in liver diseases. Cell Mol Immunol 2006, 3:333-340

15. Nicholson-Weller A, Halperin JA: Membrane signaling by complements C5b-9, the membrane attack complex. Immunol Res 1993 12:244-257

16. Benzaquen LR, Nicholson-Weller A, Halperin JA: Terminal complement proteins $\mathrm{C} 5 \mathrm{~b}-9$ release basic fibroblast growth factor and platelet-derived growth factor from endothelial cells. J Exp Med 1994, 179:985-992 
17. Acosta J, Qin X, Halperin J: Complement and complement regulatory proteins as potential molecular targets for vascular diseases. Curr Pharm Des 2004, 10:203-211

18. Fosbrink M, Niculescu F, Rus V, Shin ML, Rus H: C5b-9-induced endothelial cell proliferation and migration are dependent on Akt inactivation of forkhead transcription factor FOXO1. J Biol Chem 2006, 281:19009-19018

19. Kilgore KS, Schmid E, Shanley TP, Flory CM, Maheswari V, Tramontini NL, Cohen H, Ward PA, Friedl HP, Warren JS: Sublytic concentrations of the membrane attack complex of complement induce endothelial interleukin-8 and monocyte chemoattractant protein-1 through nuclear factor-kB activation. Am J Pathol 1997, 150:2019-2031

20. Morgan BP: Regulation of the complement membrane attack pathway. Crit Rev Immunol 1999, 19:173-198

21. Holt DS, Botto M, Bygrave AE, Hanna SM, Walport MJ, Morgan BP: Targeted deletion of the CD59 gene causes spontaneous intravascular hemolysis and hemoglobinuria. Blood 2001, 98:442-449

22. Qin X, Krumrei N, Grubissich L, Dobarro M, Aktas H, Perez G, Halperin JA: Deficiency of the mouse complement regulatory protein $\mathrm{mCd59b}$ results in spontaneous hemolytic anemia with platelet activation and progressive male infertility. Immunity 2003, 18:217-227

23. Diepenhorst GM, van Gulik TM, Hack CE: Complement-mediated ischemia-reperfusion injury lessons learned from animal and clinical studies. Ann Surg 2009, 249:889-899

24. He S, Atkinson C, Evans Z, Ellett JD, Southwood M, Elvington A, Chavin KD, Tomlinson S: A role for complement in the enhanced susceptibility of steatotic livers to ischemia and reperfusion injury. J Immunol 2009, 183:4764-4772

25. Fondevila C, Shen XD, Tsuchihashi S, Uchida Y, Freitas MC, Ke B, Busuttil RW, Kupiec-Weglinski JW: The membrane attack complex (C5b-9) in liver cold ischemia and reperfusion injury. Liver Transpl 2008, 14:1133-1141

26. Yamada K, Miwa T, Liu J, Nangaku M, Song WC: Critical protection from renal ischemia reperfusion injury by CD55 and CD59. J Immunol 2004, 172:3869-3875

27. Qin X, Hu W, Song W, Grubissich L, Hu X, Wu G, Ferris S, Dobarro M Halperin JA: Generation and phenotyping of mCd59a and mCd59b double-knockout mice. Am J Hematol 2009, 84:65-70

28. Evans ZP, Ellett JD, Schmidt MG, Schnellmann RG, Chavin KD: Mitochondrial uncoupling protein-2 mediates steatotic liver injury following ischemia/reperfusion. J Biol Chem 2008, 283:8573-8579

29. Vriesendorp FJ, Flynn RE, Malone MR, Pappolla MA: Systemic complement depletion reduces inflammation and demyelination in adoptive transfer experimental allergic neuritis. Acta Neuropathol 1998, 95:297-301

30. Li J, Dahmen U, Dirsch O, Shen K, Gu Y, Broelsch CE: Modified sleeve anastomosis for reconstruction of the hepatic artery in rat liver transplantation. Microsurgery 2002, 22:62-68

31. Rochling FA: Evaluation of abnormal liver tests. Clinical Cornerstone 2001, 3(6):1-12

32. Bjerre M, Hansen TK, Flyvbjerg A, Tønnesen E: Simultaneous detection of porcine cytokines by multiplex analysis: development of magnetic bioplex assay. Vet Immunol Immunopathol 2009, 130:53-58

33. Hu W, Ferris SP, Tweten RK, Wu G, Radaeva S, Gao B, Bronson RT, Halperin JA, Qin X: Rapid conditional targeted ablation of cells expressing human CD59 in transgenic mice by intermedilysin. Nat Med 2008, 14:98-103

34. Hu W, Jin R, Zhang J, You T, Peng Z, Ge X, Bronson RT, Halperin JA, Loscalzo J, Qin X: The critical roles of platelet activation and reduced $\mathrm{NO}$ bioavailability in fatal pulmonary arterial hypertension in a murine hemolysis model. Blood 2010, 116:1613-1622

35. Wu G, Chen T, Shahsafaei A, Hu W, Bronson RT, Shi GP, Halperin JA Aktas H, Qin X: Complement regulator CD59 protects against angiotensin II-induced abdominal aortic aneurysms in mice. Circulation 2010, 121:1338-1346

36. Serafín A, Roselló-Catafau J, Prats N, Xaus C, Gelpí E, Peralta C: Ischemic preconditioning increases the tolerance of fatty liver to hepatic ischemia-reperfusion injury in the rat. Am J Pathol 2002 161:587-601

37. Wu G, Hu W, Shahsafaei A, Song W, Dobarro M, Sukhova GK Bronson RR, Shi GP, Rother RP, Halperin JA, Qin X: Complement regulator CD59 protects against atherosclerosis by restricting the formation of complement membrane attack complex. Circ Res 2009, 104:550-558
38. Halme J, Sachse M, Vogel H, Giese T, Klar E, Kirschfink M: Primary human hepatocytes are protected against complement by multiple regulators. Mol Immunol 2009, 46:2284-2289

39. Spiller OB, Criado-García O, Rodríguez De Córdoba S, Morgan BP Cytokine-mediated up-regulation of CD55 and CD59 protects human hepatoma cells from complement attack. Clin Exp Immunol 2000, 121:234-241

40. Longhi MP, Williams A, Wise M, Morgan BP, Gallimore A: CD59a deficiency exacerbates influenza-induced lung inflammation through complement-dependent and -independent mechanisms. Eur J Immunol 2007, 37:1266-1274

41. Sivasankar B, Donev RM, Longhi MP, Hughes TR, Davies R, Cole DS, Morgan BP, Marchbank KJ: CD59a deficient mice display reduced B cell activity and antibody production in response to T-dependent antigens. Mol Immunol 2007, 44:2978-2987

42. Pevni D, Frolkis I, Shapira I, Schwartz D, Schwartz I, Chernichovski T, Nesher N, Uretzky G: Cardioplegic ischemia or reperfusion: which is a main trigger for tumor necrosis factor production? Int J Cardiol 2008, 127:186-191

43. Libert C, Wielockx B, Grijalba B Libert C, Wielockx B, Grijalba B, Van Molle W, Kremmer E, Colten HR, Fiers W, Brouckaert P: The role of complement activation in tumor necrosis factor-induced lethal hepatitis. Cytokine 1999, 11:617-625

44. Mollnes TE, Song WC, Lambris JD: Complement in inflammatory tissue damage and disease. Trends Immunol 2002, 23:61-64

45. Tedesco F, Fischetti F, Pausa M: Complement-endothelial cel interactions: pathophysiological implications. Mol Immunol 1999, 36: 261-268

46. Conway DS, Pearce LA, Chin BS, Hart RG, Lip GY: Plasma von Willebrand factor and soluble P-selectin as indices of endothelial damage and platelet activation in 1321 patients with nonvalvular atrial fibrillation: relationship to stroke risk factors. Circulation 2002, 106 : 1962-1967

47. Vogel CW, Müller-Eberhard HJ: The cobra complement system: I. The alternative pathway of activation. Dev Comp Immunol 1985, 9:311-325

48. Harhausen D, Khojasteh U, Stahel PF, Morgan BP, Nietfeld W, Dirnagl U, Trendelenburg G: Membrane attack complex inhibitor CD59a protects against focal cerebral ischemia in mice. J Neuroinflammation 2010, 7:15

49. Baalasubramanian S, Harris CL, Donev RM, Mizuno M, Omidvar N, Song WC, Morgan BP: CD59a is the primary regulator of membrane attack complex assembly in the mouse. J Immunol 2004, 173:36843692

50. Donev RM, Sivasankar B, Mizuno M, Morgan BP: The mouse complement regulator CD59b is significantly expressed only in testis and plays roles in sperm acrosome activation and motility. Mol Immunol 2008, 45:534-542

51. Zhang $C, X u Y$, Jia $L$, Yang $Y$, Wang $Y$, Sun $Y$, Huang $L$, Qiao $F$, Tomlinson S, Liu $X$, Zhou $Y$, Song $H$ : A new therapeutic strategy for lung tissue injury induced by influenza with CR2 targeting complement inhibitor. Virol J 2010, 7:30

52. Zhao $\mathrm{H}$, Montalto MC, Pfeiffer KJ, Hao L, Stahl GL: Murine model of gastrointestinal ischemia associated with complement-dependent injury. J Appl Physiol 2002, 93:338-345

53. Zhou W, Farrar CA, Abe K, Pratt JR, Marsh JE, Wang Y, Stahl GL, Sacks SH: Predominant role for C5b-9 in renal ischemia/reperfusion injury. J Clin Invest 2000, 105:1363-1371

54. Cole DS, Hughes TR, Gasque P, Morgan BP: Complement regulator loss on apoptotic neuronal cells causes increased complement activation and promotes both phagocytosis and cell Iysis. Mol Immunol 2006, 43:1953-1964

55. Stolz DB, Ross MA, Ikeda A, Tomiyama K, Kaizu T, Geller DA, Murase N: Sinusoidal endothelial cell repopulation following ischemia/reperfusion injury in rat liver transplantation. Hepatology 2007, 46:1464-1475

56. Wang YI, Li G, Zhang Y, Gao W, Yao Z: The expression of von Willebrand factor, soluble thrombomodulin, and soluble P-selectin during orthotopic liver transplantation. Transplant Proc 2007, 39:172-175

57. Basile J, Wang L, Tarcsafalvi A Basile J, Wang L, Tarcsafalvi A, Han R, Boros P, Miller CM: Expression of GMP-140 (P-selectin) correlates with graft viability in cold-preserved rat livers. Transplantation 2000 69:2440-2442

58. Nakashima S, Qian Z, Rahimi S, Wasowska BA, Baldwin WM 3rd: Membrane attack complex contributes to destruction of vascular integrity in acute lung allograft rejection. J Immunol 2002,169:4620-4627 
59. Kirk AD, Morrell CN, Baldwin WM 3rd: Platelets influence vascularized organ transplants from start to finish. Am J Transplant 2009, 9:14-22

60. Baruch Y, Neubauer K, Shenkar L, Sabo E, Ritzel A, Wilfling T, Ramadori G: Von Willebrand factor in plasma and in liver tissue after partial hepatectomy in the rat. J Hepatol 2002, 37:471-477

61. Sun Z, Klein AS, Radaeva S, Hong F, El-Assal O, Pan HN, Jaruga B, Batkai S, Hoshino S, Tian Z, Kunos G, Diehl AM, Gao B: In vitro interleukin-6 treatment prevents mortality associated with fatty liver transplants in rats. Gastroenterology 2003, 125:202-215

62. Zhang X, Tachibana S, Wang H, Hisada M, Williams GM, Gao B, Sun Z: Interleukin-6 is an important mediator for mitochondrial DNA repair after alcoholic liver injury in mice. Hepatology 2010, 52:2137-2147
63. Zetzmann CP, Swamy OR, Loss GE Jr, Bohorquez H, Cohen AJ: Improving donor livers by inhibiting TNF- $\alpha$ production. Ochsner $J$ 2010, 10:250-255

64. Damman J, Schuurs TA, Ploeg RJ, Seelen MA: Complement and renal transplantation: from donor to recipient. Transplantation 2008 , 85:923-927

65. De Vries B, Matthijsen RA, Wolfs TG, Van Bijnen AA, Heeringa P, Buurman WA: Inhibition of complement factor C5 protects against renal ischemia-reperfusion injury: inhibition of late apoptosis and inflammation. Transplantation 2003, 75:375-382

66. Li Q, Peng Q, Xing G, Li K, Wang N, Farrar CA, Meader L, Sacks SH Zhou W: Deficiency of C5aR prolongs renal allograft survival. J Am Soc Nephrol 2010, 21:1344-1353 